\section{Students say they'll stay}

\section{Washington}

ONE year after the Tiananmen Square massacre, the flood of Chinese students arriving in the United States continues unabated. But the number of exchange students returning to China has slowed to a trickle, a trend that may make it increasingly difficult for other students still in China to follow in their footsteps.

In autumn 1989, after the June demonstration, 33,000 Chinese students were studying in the United States, by far the largest contingent outside China. The total is 4,000 more than the previous year, according to the New-York-based Institute of International Education, which recently released a report on the status of Chinese students abroad. Although new students are arriving at about the same rate as last year, fewer are returning, the institute found. State Department officials say that the number of students who have returned to China since last June is only in the hundreds, most of them officially sponsored by the Chinese government or their home universities. "The historic pattern is that officially sponsored students go back and the privately sponsored ones don't", says one official. Crackdowns at home only amplify the trend, he says.

But the undiminished influx of Chinese students since the June demonstrations has come as a surprise. New Chinese regulations that restrict study abroad and more rigorous US standards for entry have undoubtedly made it more difficult for Chinese students to travel to the United States. But grassroots support for the Chinese democracy movement has spawned new private funding and boosted efforts by US universities to provide room.

Ironically, the difficulties for Chinese students begin with the problem of obtaining a US visa. About half of those applying to the US embassy in Beijing for student visas are rejected. Beyond the standard requirements, students must prove that they will have enough money to support themselves during their studies in the United States. While it was once enough to demonstrate sufficient personal or family funds, US immigration officials are now requiring more rigorous proofs of support. Cases of students who provided bogus letters listing outside sponsors are not uncommon. When such students arrive, they often reveal that the letters were written to satisfy immigration authorities and that in fact there is no independent financial support. The school must then scramble to find some sort of grant or scholarship for the student.

Most of the students who are now allowed in are those who have proven teaching or research assistantships. Such posts are most common in science and engineering, meaning that most new visas are issued to graduate students in those areas. US academic institutions provide the largest portion of financial support to Chinese students and scholars, amounting to some $\$ 200$ million annually for teaching and research scholarships.

Once they are in, Chinese students now find it much easier to stay. Many have already taken advantage of the executive order issued by President George Bush earlier this year that allows Chinese students to remain in the United States for up to four years after their visas expire (see Nature 343, 402; 1990). Although the State Department requires that they officially apply for the exemption, "we're not going to deport them if they do nothing", one official says. That seems to suit the Chinese students - applications for visa extension under the executive order have been slow.

Staying in the United States feels right, too. "If you don't go back, that's a demonstration of a political statement, and most of us want to make that statement", says Liu Yuan of the Massachusetts-based China Information Center.

But what is good for Chinese students already in the United States may not be good for those who would like to come. The number of incoming students is expected to drop in 1990, in part because the current crop of students are not leaving and freeing the all-important teaching and research assistantships. Without assurance of funding, prospective exchange students are unlikely to get visas.

Meanwhile, China has instituted new rules requiring university graduates to work for five years before studying abroad, or to pay between $\$ 530$ and $\$ 1,275$ for each year of their Chinese college education (the money would be returned to them if they return to China within eight years). Another new regulation prohibits academics from travelling abroad more than once a year, a move that could hamper scientific exchanges.

The Chinese student movement outside China appears to be solidifying as its numbers increase. Chinese student groups rallied in dozens of locations around the world last week, commemorating the Tiananmen Square riots and celebrating the Chinese Democracy Movement. In the United States, large demonstrations were held in New York, where a replica of the Goddess of Democracy was set up, and in Washington, where activists and politicians criticized the Bush administration for allowing China to retain its 'most favored nations' status in trade negotiations.

G. Chrlstopher Anderson

\section{Small turnout in Paris}

\section{Paris}

Although the international headquarters the Federation for Democracy in China (FDC) is in Paris, only a few hundred people braved the bad weather on Sunday evening to commemorate the anniversary of the massacre of students in Tiananmen Square. In the shadow of the Eiffel Tower, on the Esplanade des Droits de l'Homme (human rights esplanade), Chinese and Europeans lit candles in memory of the dead students, read poems and listened to speeches, including a solemn address from FDC's vice-president, Wuer Kaixi, the refugee student leader who now lives in the United States.

"This time last year", said Kaixi, "the statue of the Goddess of Democracy was smashed to the ground in Beijing. In Berlin, a few months ago, it was the wall against democracy which was smashed. Now I am standing under the Eiffel Tower, under black clouds. I am sure that the Goddess of Democracy will disperse the black clouds hanging over Beijing. As a Chinese, as a student, as a human being, I pray that the Chinese will not be forgotten. We will continue to fight."

There are about 3,000 Chinese students in France, over half of them in Paris, and an estimated 40 political refugees. Last year, an organization called the Maison Chinoise pour la Democracie (MCD), was set up with donations from couturier Yves Saint-Laurent and others to help stranded and refugee students to obtain visas, accommodation and work (see Nature 340, 251; 1989).

According to Ma Tao, a young student of French literature, it is easy for students with bursaries from the Chinese government to return to China, so long as they have not been politically active. "The government encourages them", he says. But for students who have been involved with MCD or otherwise have been active, it would be dangerous to return, says $\mathrm{Ma}$ Tao.

The Chinese government is thought to have infiltrated student networks in France, including MCD, and to have put pressure on students. A number have been sufficiently worried to take out membership of the Chinese Communist party. According to articles in a new French language magazine, Sinopsis, dealing with current Chinese problems, widely read Chinese language newspapers published in Paris continue to denounce dissidents as "criminal dogs".

The small turnout for Sunday's demonstration is, says Ma Tao, a symptom of a general waning of interest in the plight of Chinese students' efforts to create political reforms. Over the past few months, the 